\title{
Sedimentary record of the Dukla Basin (Outer Carpathians, Slovakia and Poland) and its implications for basin evolution
}

\author{
Diana DIRNEROVÁ, Marta PREKOPOVÁ and Juraj JANOČKO
}

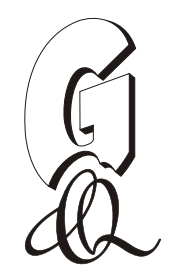

\begin{abstract}
Dirnerová D., Prekopová M. and Janočko J. (2012) - Sedimentary record of the Dukla Basin (Outer Carpathians, Slovakia and Poland) and its implications for basin evolution. Geol. Quart., 56 (3): 547-560, doi: 10.7306/gq.1039

The Late Cretaceous to Oligocene strata of the Dukla Nappe, which is a part of the accretionary wedge formed in front of the Carpathian orogen, record a history of the basin development from remnant to foreland basin stages. The lower part of the succession indicates the first stage of basin evolution characterized by turbidite systems fed from the E (NE) to W (SW). The system encompasses deposits of the Łupków and Cisna formations deposited in a channel-lobe transition (Lupków Fm.) and in sandstone-rich channelized lobes (Cisna Fm.) The transitional phase is represented by deposits of the Submenilite Formation derived from two different sources (SE and N) and deposited in a submarine slope/ramp environment. The third stage of basin evolution is marked by the advancing front of the Carpathian orogen resulting in peripheral foreland basin development. Increased tectonic activity led to a switch in sediment source from the SE to the NW, more complex topography of the basin and a change in sediment distribution. The initial phase of this stage is characterized by low-density turbidites and suspension fall-out sediments of the Menilite Fm. Discrete tectonic pulses are recorded by the thick Cergowa sandstones, mostly deposited by hybrid flows and high-density turbidity currents. A decrease in tectonic activity is suggested by heterolithic deposits of the Krosno Fm. capping the sedimentary succession.
\end{abstract}

Diana Dirnerová, Marta Prekopová and Juraj Janočko, Institute of Geosciences, Technical University of Košice, Letná 9, 04001 Slovakia,e-mails: diana.dirnerova@tuke.sk,marta.prekopova@tuke.sk, juraj.janocko@tuke.sk(received: October 12, 2011; accepted: July 17, 2012; first published online: September 06, 2012).

Key words: Dukla Unit, facial analysis, deep-marine environment, submarine fan, basin evolution.

\section{INTRODUCTION}

New methodologies and approaches in the study of deep marine deposits, including studies of outcrops at seismic scales (e.g., Hurst et al., 1999; Hodgson et al., 2006), seismic investigations (Deptuck et al., 2008), laboratory experiments and numerical simulations (McCaffrey et al., 2003; Huang et al., 2007) have brought new insights into process-response models that relate the transport process to the facies distribution and geometry of sedimentary bodies. The resulting information can be not only applied to understanding of the evolution of sedimentary systems and related sedimentary basin evolution but also to prospection for new hydrocarbon reservoirs. One of the benefits of such studies is the possibility to use complex models in regions with scarce exposures in order to complete the missing parts of a "geological puzzle".

The main aim of this article is to present a detailed facies analysis and interpretation of depositional environments of strata and to discuss the implications for the evolution of the Dukla Basin in the Outer Carpathian Flysch Belt (Fig. 1).

\section{GEOLOGICAL SETTING, TECTONIC AND PALAEOGEOGRAPHIC FRAMEWORK}

The Dukla Nappe, emerging at the surface in southeastern Poland and stretching southeastwards across Polish and Slovakian territory to the Ukraine (Fig. 1), represents a part of the the Outer Carpathians traditionally called Outer Flysch Belt in Slovakia. It belongs to the Fore-Magura group of nappes occurring between Magura to the south and the Silesian nappes to the north.

Stratigraphically, the Dukla Unit in the area studied comprises the Łupków Formation overlain by the Cisna, Submenilite and Menilite formations, which are, in turn, capped by the Krosno Formation (e.g., Leško and Samuel, 1968; Koráb and Durkovič, 1978; Figs. 1 and 2). Older strata have only been found in the Ukraine (e.g., Jankowski et al., 2004). 


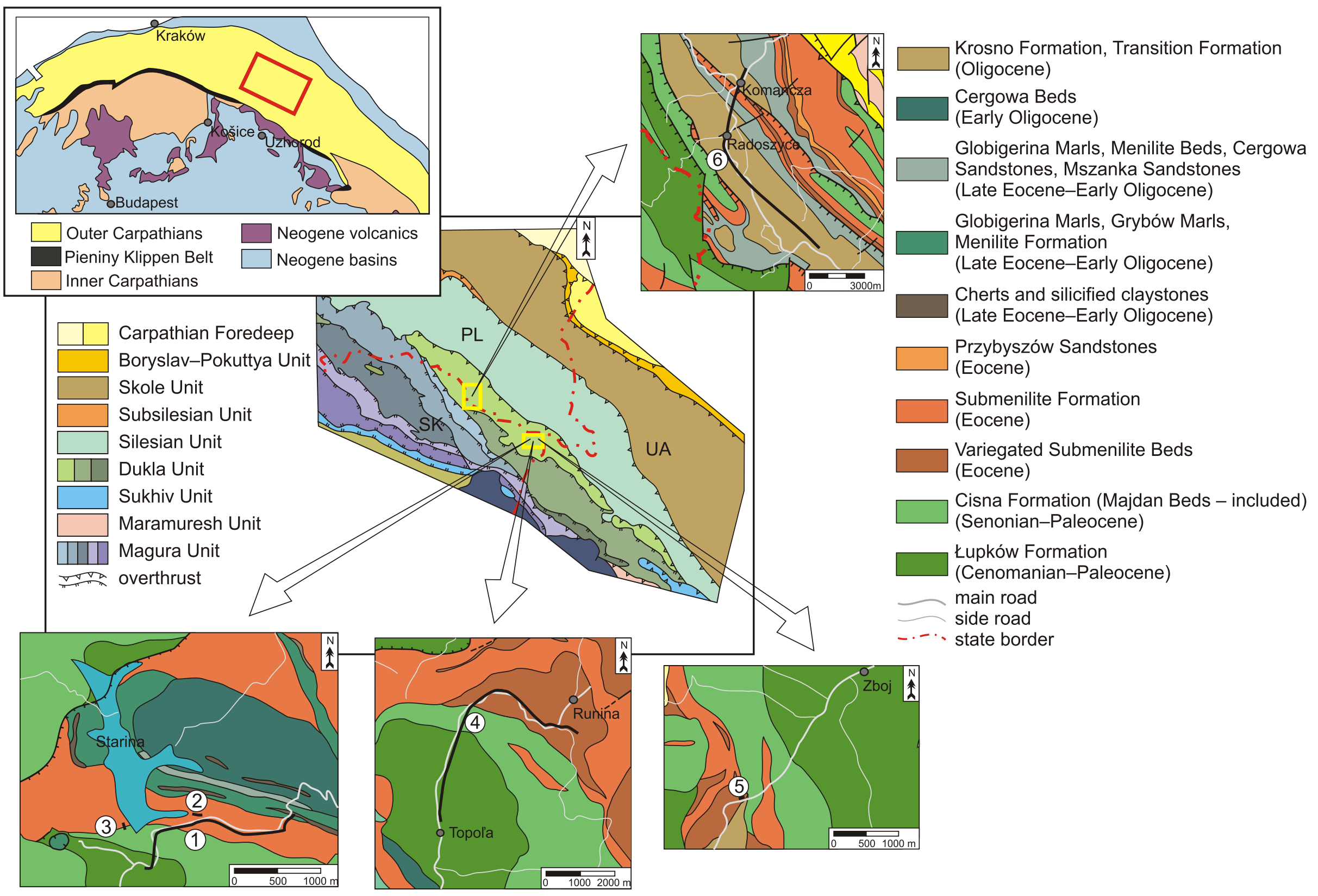

Fig. 1. Location of the study area (geology after Koráb, 1983; Kováč et al., 1998; Jankowski et al., 2004; modified) 


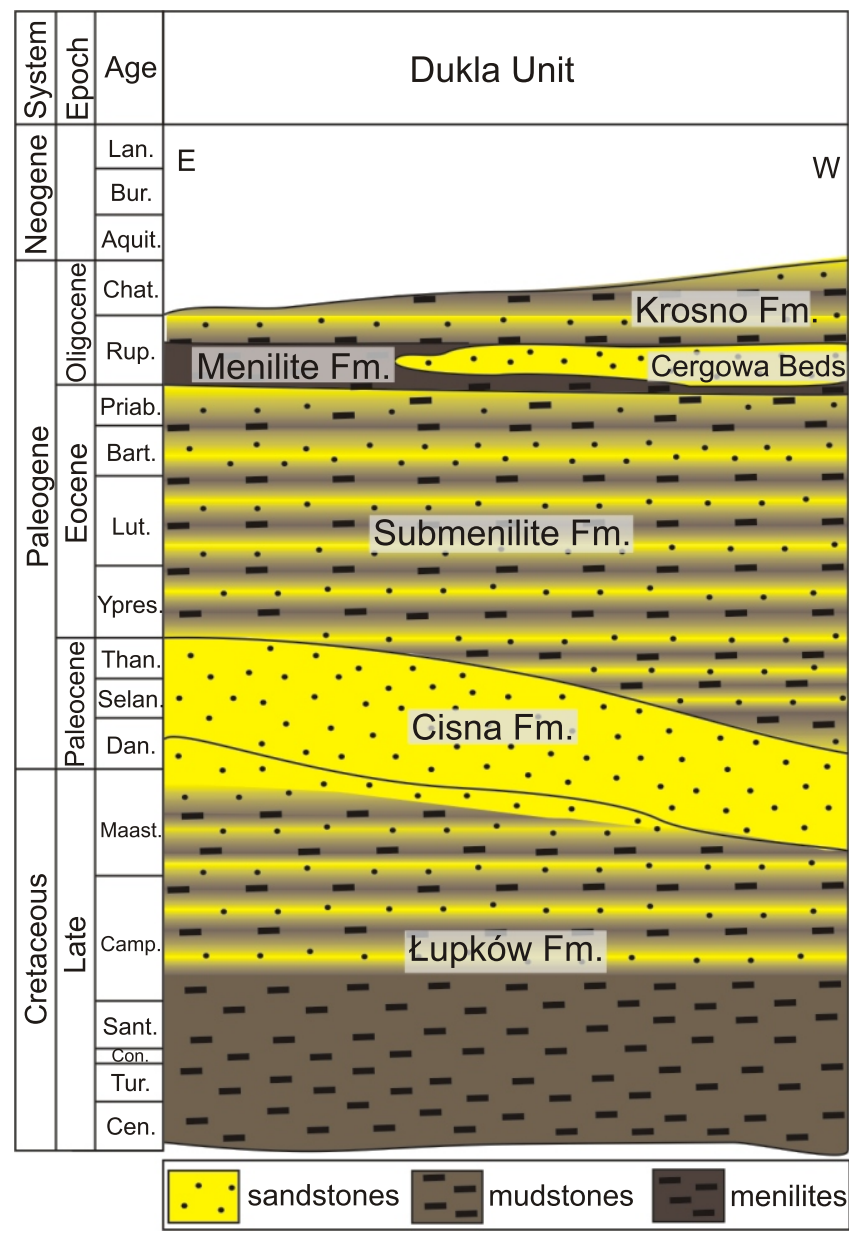

Fig. 2. Stratigraphic column of the Dukla Unit in the area studied

The Łupków Formation (Cenomanian-Paleocene) is characterized by a high content of mudstones (60-90\% according to Leško and Samuel, 1968) and convolute laminated sandstones. The volume and thickness of sandstones increases upwards. Palaeoflow indicators suggest a source area located in the E (NE; Koráb and Durkovič, 1978).

The deposits of the Łupków Formation grade upwards into the Cisna Formation (Senonian-Paleocene) which is characterized by a dominance of thick sandstones (up to $6 \mathrm{~m}$ ) with occasional microconglomerates at their bases (Koráb and Durkovič, 1978). Study of sole marks shows the main palaeoflow direction from the NE to the SW and from the N to the S (Leško and Samuel, 1968).

The Submenilite Formation (Eocene) is defined as a fining upwards succession of alternating sandstone and mudstone beds that contain many ichnofossils (Koráb and Durkovič, 1978). Koráb and Ďurkovič (1978) described two palaeoflow directions; a main longitudinal direction from the SE towards the NW and a minor, lateral direction from the N (NE) towards the $\mathrm{S}(\mathrm{SW})$. The sandstones deposited by different palaeoflows have different mineralogical compositions indicating diverse source areas.

The finest deposits are represented by the Menilite Formation (Early Oligocene) mostly composed of mudstones and menilite type claystones with minor occurrence of sandstones and pelocarbonates (Koráb and Ďurkovič, 1978). This fine-grained unit contains several thick (from 5 to $50 \mathrm{~m}$ ) sandstone intervals (e.g., Mszanka Sandstone, Cergowa Sandstone, Metresa Bed; Leško and Samuel, 1968; Koráb and Ďurkovič, 1978; Ślączka and Walton, 1992).

The sedimentary succession is terminated by the Krosno Formation (Oligocene) characterized by heterolithic deposits. The clastic material of the fine-grained sandstones was delivered to the Dukla Basin from the NW (Ślączka and Kaminski, 1998).

The deposits are generally considered to have been deposited in a remnant ocean basin transformed into a peripheral foreland basin related to the evolution of the Carpathian orogen in the Late Eocene-Early Oligocene (Oszczypko, 1999; Poprawa et al., 2002; Golonka et al., 2011).

Two different phases were recognized during the palaeogeographic evolution of Dukla Basin. Until the end of the Late Cretaceous and the beginning of the Paleogene the Dukla Basin was a part of the Magura Basin (Cieszkowski, 2002; Oszczypko, 2006; Malata and Poprawa, 2006; Pszonka, 2009). Communication between the basins is shown by similarities of the Łupków and Cisna formations in the Dukla Unit and the Inoceramus Beds in the Magura Unit (Ślączka, 1971; Golonka et al., 2000; Cieszkowski 2002). At this time, the Silesian and Bukowiec Palaeo-Ridges separated the Magura and Dukla realm from the Silesian Basin to the north (Ślączka, 2005). According to Bak and Wolska (2005) the eastern part of the Dukla Basin was bordered by a promontory of the Marmarosh Massif that supplied sediments that now comprise the Cisna Formation during the Paleocene.

During the Eocene and Oligocene, the emerging Grybów Palaeo-Ridge resulted in at least partial separation of the Dukla and Magura basins (e.g., Ondra and Hanák, 1989; Cieszkowski, 2002). However, the subsiding Silesian Palaeo-Ridge facilitated communication between the Dukla and Silesian basins at that time (e.g., Ślączka and Walton, 1992; Cieszkowski, 2002). Relative sea level fall as a result of eustasy and tectonics (e.g., Poprawa et al., 2002; Oszczypko et al., 2002; Oszczypko, 2006; Soták, 2010) around the Priabonian Rupelian boundary (e.g., Oszczypko, 1999; Oszczypko et al., 2002; Poprawa et al., 2002; Golonka et al., 2003) controlled palaeogeographical changes influencing water circulation, with resulting deposition now mostly represented by fine-grained strata of the Menilite Formation, typical of a larger part of the Outer Carpathian realm (e.g., Oszczypko et al., 2002).

The present-day position of the Dukla Nappe is a result of Late Oligocene to Early Miocene tectonic events (Oszczypko et al., 2002; Golonka et al., 2003; Oszczypko-Clowes and Oszczypko, 2004; Nemčok et al., 2006), resulting in detachment of the Late Cretaceous to Oligocene strata from their substrate and their removal towards the N and NE (e.g., Nemčok et al., 2006; Oszczypko, 2006).

\section{LOCALIZATION OF STUDY AREA}

Six sedimentary profiles of strata belonging to the Dukla Unit with a total length of $757 \mathrm{~m}$ were analysed "bed-by-bed" on the Slovakian (5) and Polish (1) territories (Fig. 1). The first three profiles lie close to the dam at Starina ( $8 \mathrm{~km}$ NE of Snina, NE Slovakia, Fig. 1) and amount to $502 \mathrm{~m}$ in thickness. Pro- 
file 1 records strata of the Cisna, Submenilite and Menilite formations exposed along the main road from Stakčín to Príslop. The strata of profiles 2 and 3 crop out on the right and left sides of the dam, respectively and comprise a succession of Submenilite Formation overlying the uppermost part of the Cisna Formation. The fourth profile is located along the main road between Runina and Topol'a (23 km from Snina, NE Slovakia, Fig. 1) and comprises $125 \mathrm{~m}$ of strata assigned to the Łupków, Cisna and Submenilite formations. Around the villages of Zboj and Uličské Krivé the fifth, $15 \mathrm{~m}$ long profile occurs and shows strata of the Submenilite Formation. A 115 m thick succession (profile 6) belonging to the Menilite and Krosno formations occurs $25 \mathrm{~km} \mathrm{~S}$ of Sanok in Poland (Fig. 1).

The sections described provide the best exposures of the Dukla Unit and were used for detailed bed-by-bed logging with a resolution of $1 \mathrm{~cm}$. Where possible, lateral trends of facies were documented. Facies descriptions and interpretations are given in Table 1 and Figures 3, 4 and 5. Interpretation is given of depositional processes of the facies associations distinguished and interpretation of the depositional environment is made (see Table 2 and Fig. 6).

Sedimentary facies distinguished in the study area with their descriptions and interpretations of depositional process

\begin{tabular}{|c|c|c|c|}
\hline Name of the facies & Code & Description & Depositional process \\
\hline \multirow[b]{2}{*}{ Debrite } & D1 & $\begin{array}{l}\text { - medium-grained sandstone containing mudstone } \\
\text { clasts chaotically distributed throughout whole bed } \\
\text { - mudstone clasts up to } 7 \mathrm{~cm} \text {, chaotically arranged } \\
\text { - sharp and erosional base } \\
\text { bed thickness up to } 20 \mathrm{~cm}\end{array}$ & \multirow[b]{2}{*}{$\begin{array}{l}\text { - en-masse freezing from debris flows (Lowe, 1982; } \\
\text { Nemec and Steel, 1988) }\end{array}$} \\
\hline & D2 & $\begin{array}{l}\text { - fine- to medium-grained sandstone } \\
\text { - amalgamated beds with thickness up to } 190 \mathrm{~cm} \\
\text { - subangular to suboval chaotically dispersed mudstone } \\
\text { clasts of } 0.2-0.8 \mathrm{~cm} \text { size } \\
\text { - locally aligned mudstone clasts up to } 6 \mathrm{~cm} \\
\text { - mostly sharp bases, occasionally with sole marks and } \\
\text { load casts }\end{array}$ & \\
\hline Massive sandstone & Sm & $\begin{array}{l}\text { - fine- to medium-grained amalgamated sandstone } \\
\text { - variable bed thickness, for fine-grained sandstone } \\
\text { between } 1-10 \mathrm{~cm} \text {, for medium-grained sandstone } \\
\text { up to } 300 \mathrm{~cm} \\
\text { - sharp or wavy bases locally with sole marks } \\
\text { - locally aligned mudstone clasts of } 0.5-7 \mathrm{~cm} \text { diameter }\end{array}$ & $\begin{array}{l}\text { - frictional freezing from hyperconcentrated density flow } \\
\text { (Mulder and Alexander, 2001) } \\
\text { - frictional freezing and suspension fall-out from } \\
\text { concentrated density flow (Lowe, 1988; Mulder et al., } \\
\text { 2001) } \\
\text { - continuous aggradation from sustained high density } \\
\text { turbidity currents (Kneller and Branney, 1995; Stow and } \\
\text { Johansson, 2000; Plink-Björklund and Steel, 2004) } \\
\text { - collapse fall-out beyond the hydraulic jump from } \\
\text { concentrated density and turbidity flow (Stow and } \\
\text { Johansson, 2000) }\end{array}$ \\
\hline $\begin{array}{l}\text { Normal graded } \\
\text { sandstone }\end{array}$ & $\mathrm{Sg}$ & $\begin{array}{l}\text { - fine- to medium-grained sandstone } \\
\text { - highly variable thickness of beds from } 6 \text { to } 110 \mathrm{~cm} \\
\text { - sharp or scoured bases, locally with sole marks }\end{array}$ & $\begin{array}{l}\text { - suspension fall-out within decelerating and waning flow, } \\
\text { i.e. Ta division in Bouma sequence (Amy and Talling, } \\
\text { 2006) } \\
\text { - progressive aggradation from concentrated flow } \\
\text { (Kneller and Branney, 1995) }\end{array}$ \\
\hline $\begin{array}{l}\text { Parallel-laminated } \\
\text { sandstone }\end{array}$ & Spl & $\begin{array}{l}\text { - fine-grained sandstone } \\
\text { - bed thickness not exceeding } 35 \mathrm{~cm} \\
\text { - sharp or scoured bases, locally with sole marks }\end{array}$ & $\begin{array}{l}\text { - deposition from tractional flow (Pickering et al., 1986) } \\
\text { - Tb division in Bouma sequence (Bouma, 1962) }\end{array}$ \\
\hline $\begin{array}{l}\text { Ripple and trough } \\
\text { cross-laminated } \\
\text { sandstone }\end{array}$ & $\mathrm{Srcl} / \mathrm{tcl}$ & $\begin{array}{l}\text { - fine- to medium-grained sandstone } \\
\text { - bed thickness between } 1 \text { to } 19 \mathrm{~cm} \\
\text { - sharp or scoured bases }\end{array}$ & $\begin{array}{l}\text { - result of migration of } 2 \mathrm{D} \text { or } 3 \mathrm{D} \text { ripples (Reineck and } \\
\text { Singh, 1980) } \\
\text { - Tc division in Bouma sequence }\end{array}$ \\
\hline $\begin{array}{l}\text { Hummocky cross- } \\
\text { stratified sandstone }\end{array}$ & Shcs & $\begin{array}{l}\text { - fine-grained sandstone } \\
\text { - bed thickness to } 20 \mathrm{~cm} \\
\text { - wavelenght of hummocks exceeding } 60 \mathrm{~cm} \\
\text { - sharp bases }\end{array}$ & $\begin{array}{l}\text { - deposition via waves forming on the contact of } \\
\text { the flow with the ambient water (Prave and Duke, 1990; } \\
\text { Mulder et al., 2009) }\end{array}$ \\
\hline $\begin{array}{l}\text { Convolute-laminated } \\
\text { sandstone }\end{array}$ & Scl & $\begin{array}{l}\text { - fine- to medium-grained sandstone } \\
\text { - thickness of beds up to } 78 \mathrm{~cm}\end{array}$ & - transformation of metastable sediment (Dżułyński, 1996) \\
\hline Massive mudstone & $\mathrm{Mm}$ & $\begin{array}{l}\text { - bed thickness up to } 39 \mathrm{~cm} \\
\text { - dark grey to black } \\
\text { - sharp bases }\end{array}$ & $\begin{array}{l}\text { - fall-out from suspension, i.e. pelagic/hemipelagic } \\
\text { sedimentation } \\
\text { - Te division in Bouma sequence }\end{array}$ \\
\hline $\begin{array}{l}\text { Parallel-laminated } \\
\text { mudstone }\end{array}$ & Mpl & $\begin{array}{l}\text { - highly variable bed thickness from } 1 \text { to } 73 \mathrm{~cm} \\
\text { - light to dark grey color } \\
\text { - sharp bases }\end{array}$ & $\begin{array}{l}\text { - fall-out from suspension } \\
\text { - Te division in Bouma sequence }\end{array}$ \\
\hline $\begin{array}{l}\text { Ripple-laminated } \\
\text { muddstone }\end{array}$ & Mrcl & $\begin{array}{l}\text { - very thin to thin beds from } 2 \text { to } 13 \mathrm{~cm} \\
\text { - light grey to black color } \\
\text { - sharp bases }\end{array}$ & $\begin{array}{l}\text { - deposition from very fine-grained turbidity flow } \\
\text { - reworking by bottom current }\end{array}$ \\
\hline $\begin{array}{l}\text { Menilite-type } \\
\text { claystone }\end{array}$ & $\mathrm{Me}$ & $\begin{array}{l}\text { - thickness of beds up to } 710 \mathrm{~cm} \\
\text { - black color } \\
\text { - sharp bases }\end{array}$ & $\begin{array}{l}\text { - fall-out from suspension, i.e. pelagic/hemipelagic } \\
\text { sedimentation under anoxic conditions (Puglisi et al., } \\
\text { 2006) }\end{array}$ \\
\hline
\end{tabular}



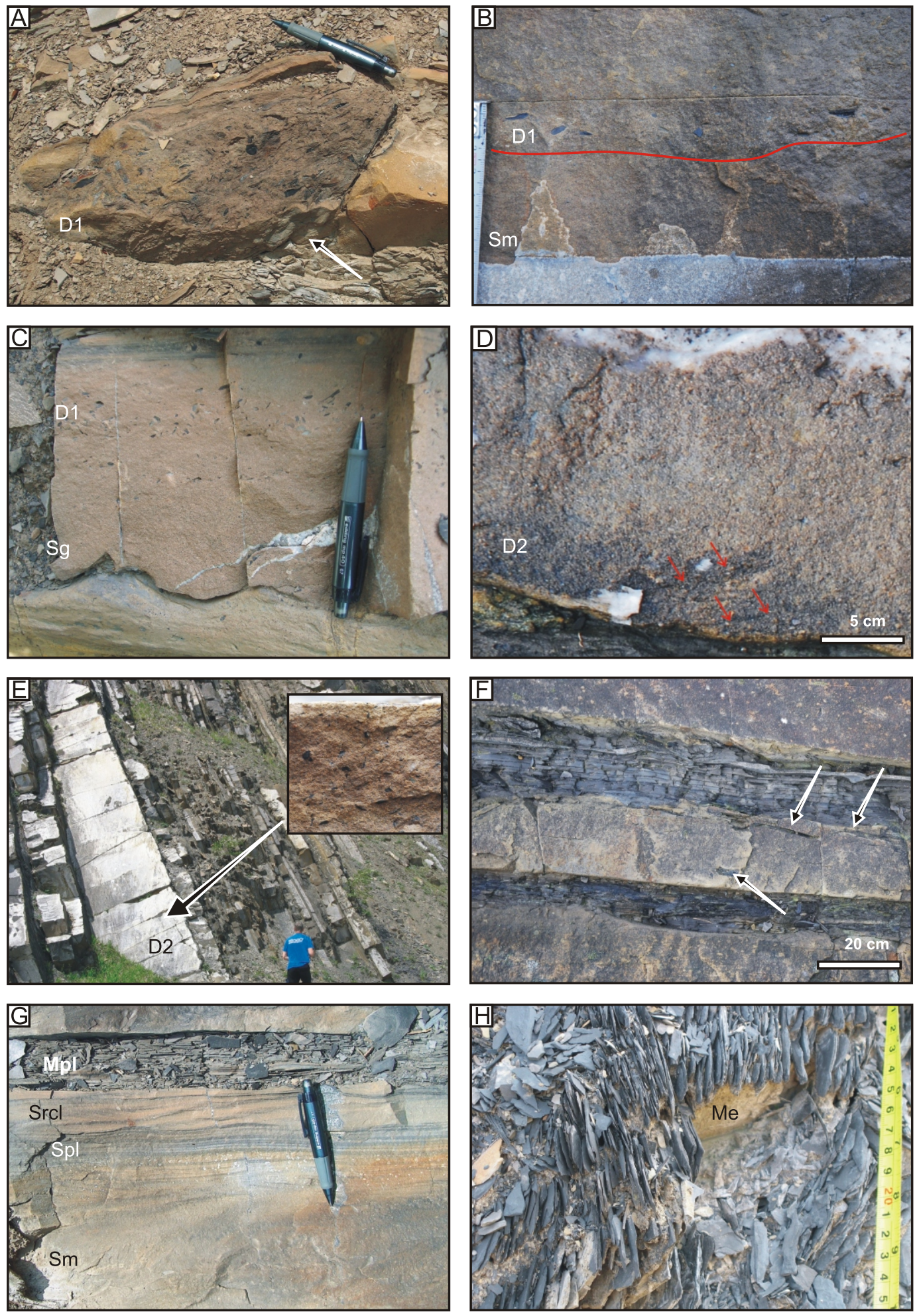

Fig. 3. Photos of facies and facies associations described in the Cergowa Beds (profile 1)

A - debrite (facies D1) - note the thin bed of sandstone at its base (arrow). Flute casts at the base indicate its deposition from turbulent flow, which created a scour later filled by debrite; B, C - linked debrites consisting of massive and normally graded sandstone at the base, capped by debrites. The debrite in Figure 3 is capped by parallel-laminated fine sandstone with alternation of darker and lighter laminae suggesting segregation of clay aggregates; $\mathbf{D}$ - massive sandstone with dispersed mudstone clasts (facies D2), the arrows mark the shear bands formed during the freezing of sediment; $\mathbf{E}$ - thick amalgamated beds of massive sandstone with dispersed mudstone clasts (facies D2) - close-up showing the composition of the sandstones; $\mathbf{F}$ - massive sandstone with floating mudstone clasts (facies Sm), arrows mark sandstone top bed injection of mud resulting from rip-down of the overlying mud and mudstone clasts deposited by continuous aggradation from high-density turbidity currents; $\mathbf{G}$ - deposit of low-density turbidity currents with divisions of the Bouma sequence; $\mathbf{H}$ menilite-type claystones (facies Me), the black colour is due to high organic ( $>4 \%)$ content 

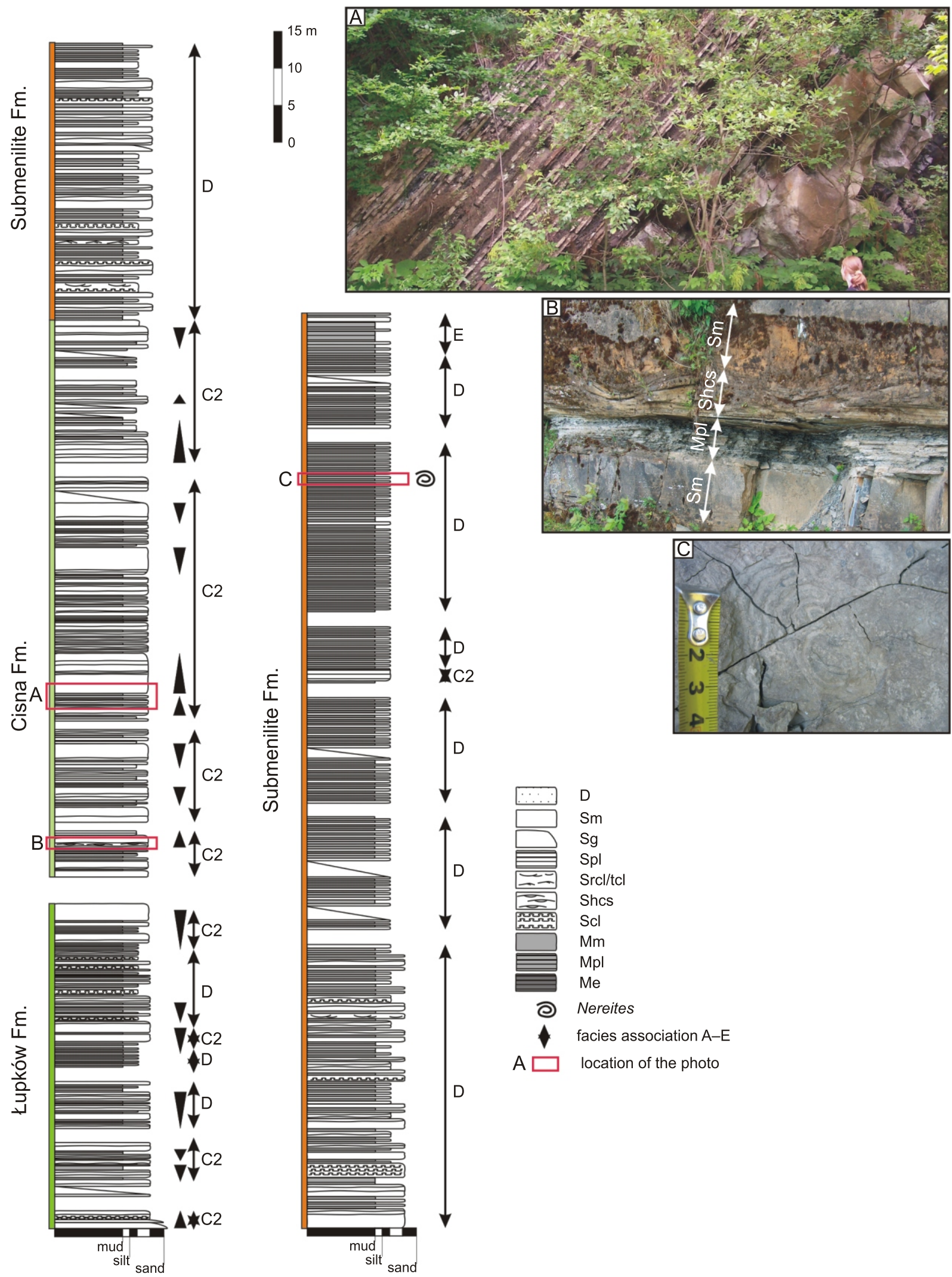

Fig. 4. Simplified composited sedimentary profiles of the Lupków (profile 4), Cisna (profiles 1 and 3) and Submenilite (profiles 1 and 3 ) formations

A - rhythmic alternation of thin beds of sandstone and mudstone interpreted as interlobe deposits, passing upwards into thick sandstones indicating channelized lobes; $\mathbf{B}$ - hummocky cross-stratified sandstone whose origin is related to the interface between the flow and ambient water; $\mathbf{C}$ - the ichnofossil Nereites as one of the indicators of a deep-water environment; for explanation of facies codes see Table 1 


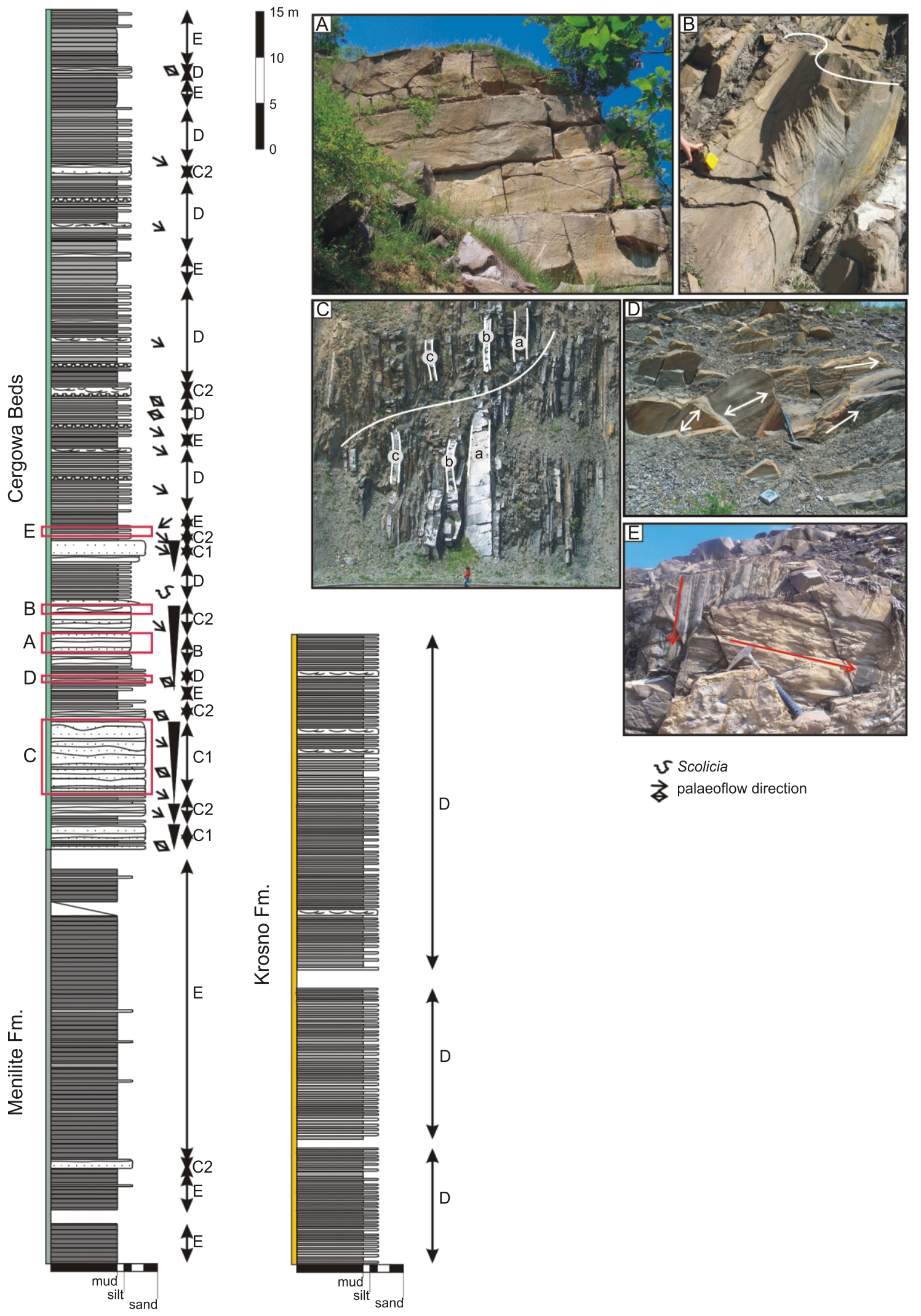

Fig. 5. Simplified composite sedimentary profiles of the Menilite (profiles 1 and 6) and Krosno (profile 6) formations

$\mathbf{A}$ - thick channelized sandstones of the Metresa Bed; $\mathbf{B}$ - synsedimentary fold; $\mathbf{C}$ - facies association $\mathbf{C} 2$. The fault throw is indicated by beds marked by letters a,b,c; $\mathbf{D}$ - palaeoflow indicators at the bases of Cergowa sandstone beds suggest gradual deviation of the flow due to local topography; $\mathbf{E}$ - two perpendicular palaeoflow directions of the Cergowa sandstones (arrows) resulting from dissected topography of the basin floor; for explanations see Figure 4 
Facies and facies associations distinguished in the sedimentary record analysed with their descriptions and interpretations

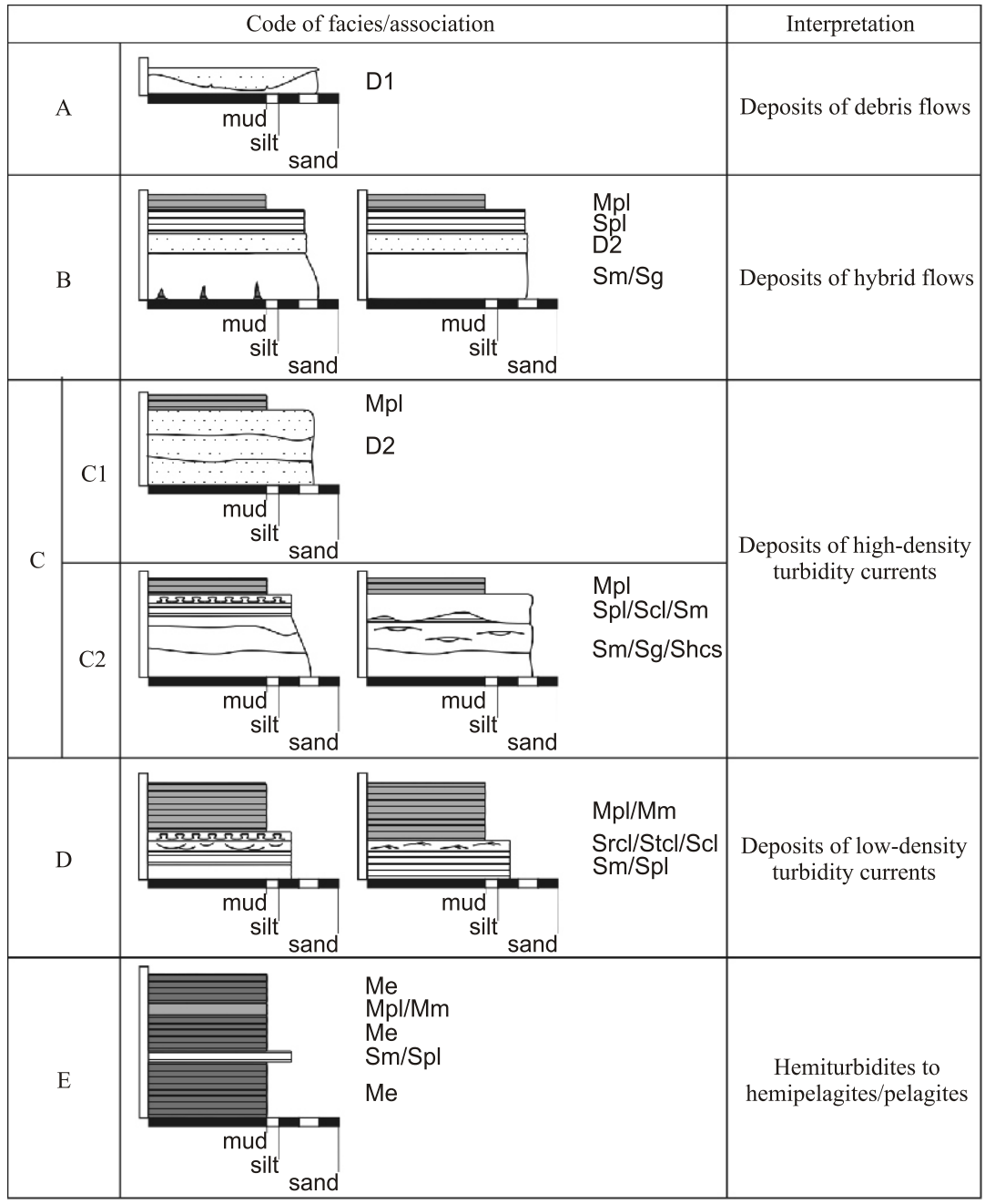

For explanation of facies codes see Table 1

\section{SEDIMENTS AND SEDIMENTARY ENVIRONMENTS}

The sedimentary succession studied consists of debrites, sandstones and mudstones with varying net-to-gross ratio, together with ichnofacies and foraminifera assemblages suggest different positions in a turbidite system and related deep-water environment in the evolving Dukla Basin during the Paleocene to Oligocene interval. Based on general indicators of palaeobathymetry, we here use the term "deep-water deposits" for the sediments deposited below storm-wave base.

Bed-by-bed description of the succession revealed 11 lithofacies based on grain size and sedimentary structures (Table 1 and Fig. 3): the debrites are represented by (1) matrix-supported conglomerates composed of pebble- to cobble-sized mudstone clasts within a sandstone matrix and (2) medium-grained sandstones with occasional granule-sized mudstone clasts. The sandstone facies includes (1) massive, fine- to medium-grained sandstone and massive sandstone with chaotically dispersed granule-sized mudstone clasts; (2) nor- mally graded medium- to fine-grained sandstone; (3) fine-grained sandstones with various traction structures and (4) convolute laminated sandstone. The mudstone facies is composed of massive, parallel and ripple laminated mudstones. A specific facies, occurring in the upper part of the succession studied, is menilite-type claystone (Table 1).

The sediments analysed were deposited by several processes as suggested by the individual facies and by the facies associations (Table 2). Hence, we were able to recognize the following deposit types:

\section{DEPOSITS OF DEBRIS FLOWS}

Medium-grained, mud-rich sandstone with chaotically distributed mudstone clasts are interpreted as the product of cohesive debris flows. The mudstone clasts varies from 0.5 to $10 \mathrm{~cm}$ across, and are often contorted. The base of debris flow beds is sharp and loaded with common flame structures. 


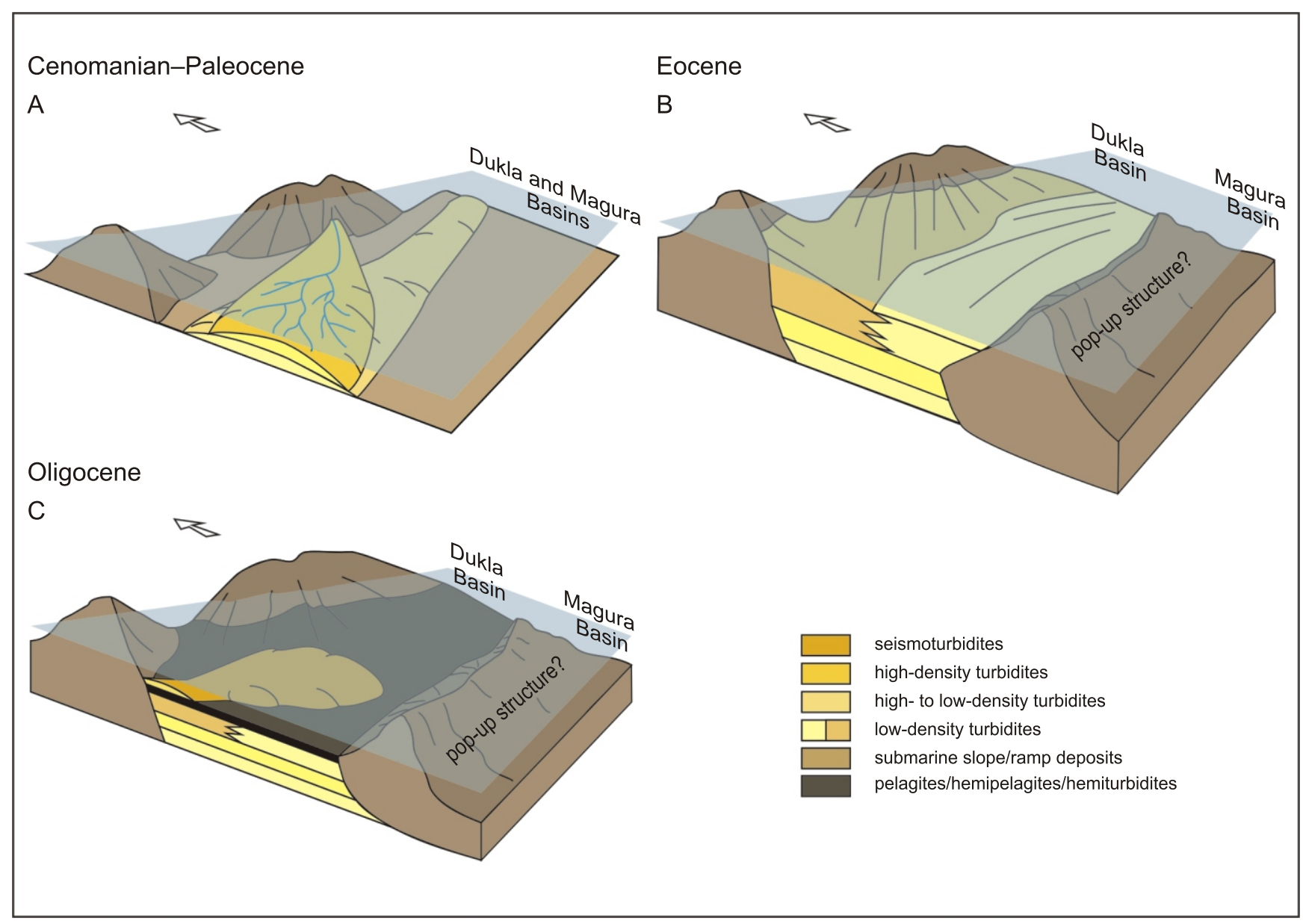

Fig. 6. Evolution of the Dukla Basin based on the deposits analysed

A - first stage of evolution interpreted as a remnant ocean basin with deposition of high- to low-density turbidites in a channel-lobe transition (Łupków Fm.) and channelized lobe (Cisna Fm.); B - transitional stage from remnant ocean to peripheral foreland basin with deposition of the Submenilite Fm. from two different sources; $\mathbf{C}$ - third stage of evolution recorded by the Menilite Fm. deposited in a peripheral foreland basin. Fines represent a starved phase of basin evolution, and the Cergowa sandstones are interpreted as seismoturbidites representing seismic/tectonic activity

\section{DEPOSITS OF HYBRID FLOWS}

These deposits are characterized by couplets of massive or normally graded sandstone overlain by medium-grained sandstone containing small mudstone clasts (debrite). This couplet may rarely be overlain by parallel laminated fine sandstone showing alternations of darker and lighter laminae, thus comprising triplets of sandstone - debrite - sandstone (e.g., McCaffrey and Kneller, 2001; Haughton et al., 2009; Fig. 3). Organic matter is common on the bedding planes of the upper sandstones. The entire association is sandwiched between mudstone. The massive and graded sandstones have sharp or loaded bases with water escape structures (flame structures) and a distinct boundary with the overlying debrite.

The deposits described are interpreted as deposits of hybrid flows (e.g., Haughton et al., 2003) consisting of high-density turbidite sandstone at the base, overlying linked debrite, which is, in turn, capped by low-density turbidite sandstone (e.g., Ito, 2008; Felix et al., 2009; Pritchard and Gladstone, 2009). The massive or graded sandstone at the base is correlated with the H1 division of Haughton et al. (2009), while the overlying debrite and laminated fine sandstone corresponds with $\mathrm{H} 3$ and H4 divisions, respectively.

Similar hybrid beds are recognized widely at the distal and lateral margins of turbidite systems (Haughton et al., 2009). The common association with abundant carbonaceous matter indicates probable linkage to the contemporaneous shelf.

\section{DEPOSITS OF HIGH-DENSITY TURBIDITY CURRENTS}

The deposits of high density turbidity currents (according to Lowe, 1982) are represented by three facies associations. The first association, $\mathrm{C} 1$, consists of massive sandstone with dispersed mudstone clasts overlain by thin beds of parallel-laminated mudstone. The sandstone to mudstone ratio is 12:1. The base of the sandstone beds is sharp, scoured or loaded and frequently shows a variety of sole marks. The beds are often amalgamated, building bedsets up to $9 \mathrm{~m}$ thick.

The deposits described are interpreted as products of high-density turbidity currents due to widespread sole marks indicating turbulence (e.g., Hodgson, 2009). The massive 
structure of the sandstones results from suppression of turbulence most probably when turbulent flow slowed e.g., due to a hydraulic jump at a change in slope angle (Talling et al., 2007) or as a result of erosional bulking as suggested by the small mudstone clasts dispersed in the sandstones (e.g., Ricci Lucchi and Valmori, 1980; Talling et al., 2004). Thin caps of parallel-laminated mudstone reveal subsequent deposition from following dilute turbidites.

The second association, C2, is characterized by thick-bedded massive or normally graded sandstone, or by convolute-laminated sandstone overlain by parallel-laminated sandstone and mudstone. The base of beds is sharp, scoured and loaded. Beds are often amalgamated with a mean thickness of $3.2 \mathrm{~m}$; however, the thickness may reach $10 \mathrm{~m}$ locally. The mean sandstone to mudstone ratio is $5: 1$.

The association is interpreted as a turbidity current deposit due to basal scours and sole marks indicating flow turbulence, normal grading and tractional structures at the top of the succession. The thick massive sandstone interval at the base of the succession suggests high flow concentration and probably is analogous to the $\mathrm{S}_{3}$ interval of high-density turbidity currents described by Lowe (1982).

\section{DEPOSITS OF LOW-DENSITY TURBIDITY CURRENTS}

The deposits of low-density turbidity currents are characterized by an association of fine- to medium-grained sandstone passing into mudstone, and mostly represented by heterolithic deposits. The sandstone shows a wide range of tractional structures from parallel-laminated, ripple/trough-cross-laminated and convolute-laminated ones. The overlying mudstone is ripple- and/or parallel-laminated. The sandstone to mudstone ratio is $2: 1$ to $1: 5$. The mean thickness of strata in the association is $4 \mathrm{~m}$ with a maximum of $25 \mathrm{~m}$.

The abundance of tractional structures points to deposition by turbiditic curents with preservation of Bouma $\mathrm{Tb}, \mathrm{c}$ and d divisions (Bouma, 1962; Hiscott et al., 1997).

\section{HEMITURBIDITES AND HEMIPELAGITES/PELAGITES}

These deposits are represented by brownish dark to black claystone including black, hard, fissile and siliceous claystone with a high organic content (menilite) and massive and/or parallel-laminated mudstone. The strata described are locally interrupted by thin beds of parallel-laminated fine- to medium-grained sandstones.

The texture and structure of these beds suggest deposition by suspension fall-out and and hemiturbidites. The few thin beds of sandstone are thought to have been deposited by low-density turbidites.

\section{INTERPRETATION OF DEPOSITIONAL ENVIRONMENT}

The sedimentary section analysed is one of the best preserved sections in the Dukla Unit showing the succession of the basin fill from the base to the top. The geological background (e.g., Koráb and Ďurkovič, 1978; Oszczypko, 1999; Malata and Poprawa, 2006), sedimentary structures, ichnofossil indices (Uchman et al., 2006) and palaeobathymetry defined on the base of foraminiferal assemblages (Olszewska and Malata, 2006) strongly suggest deposition in a turbidite system developed in the range of outer shelf (?) to abyssal zones.

The section studied starts with the uppermost part of the Łupków Formation (Cenomanian-Paleocene), which mainly consists of high- and low-density turbidity deposits (Fig. 4). The sandstone beds with occasional scoured and fluted beds show several upwards thickening cycles several metres thick consisting of thin $(5-10 \mathrm{~cm})$ beds at the base and medium-thick $(40 \mathrm{~cm})$ beds at the top. The sandstone to mudstone ratio is $3: 1$. Flutes on the base of the sandstone indicate a palaeoflow direction from $\mathrm{E}(\mathrm{NE})$ to $\mathrm{W}(\mathrm{SW})$.

Thin- and medium-thick sandstone beds deposited by highand low-density turbidity currents, erosional features such as scours and flutes and thickening-upwards cycles indicate deposition at the channel-lobe transition with an overall progradational trend (Postma et al., 2009). Medium- to coarse-grained sandstones, in places containing granules at the base and convolute lamination, suggest high competence of the currents and high sedimentation rates. Such conditions can be assumed to occur in a channel-lobe transitional area.

The interval of upward thickening cycles of sandstone beds separated by mudstones (Łupków Fm.) passes upwards into sandier deposits belonging to the Cisna Formation (Senonian-Paleocene, Figs. 1 and 4). The interval is typified by predominant medium- to coarse-grained, thick, often scoured sandstone beds. The palaeoflow directions based on flute marks are from NE to SW. The frequently amalgamated sandstone beds with a maximum measured thickness of $12 \mathrm{~m}$ are separated by thin mudstone intervals. The sandstones are mostly massive or built of a succession of massive/normal graded, parallel- and convolute-laminated intervals (Bouma Ta, b, c divisions), where the upper interval of tractional structures is rarely replaced by hummocky-cross stratification (Fig. 4). Foraminiferal assemblages show deposition in the lower bathyal zone (e.g., Oszczypko, 2004; Uchman et al., 2006).

The thick, frequently scoured sandstone beds, amalgamation and massive sandstones suggest deposition by high-density turbidity currents close to the channelized part of a turbidite system. The occurrence of structures resembling hummocky-cross stratification are thought to be a result of up-current migrating waves (antidunes) triggered by high-energy turbidity currents that are common close to main turbidity current conduits (e.g., Mulder et al., 2009).

The sandy interval of the Cisna Formation passes into thin (3-7 cm) sandstone beds alternating with mudstones (Fig. 4) assigned to the Submenilite Formation (Eocene). The transition between thick sandstone beds of the Cisna Formation and the overlying strata of the Submenilite Formation is gradual and marked by an increase in mudstone beds. The sandstone:mudstone ratio varies from $2: 1$ in the lower part to $1: 5$ in the upper part. The sandstone shows mostly $\mathrm{Tb}, \mathrm{c}, \mathrm{d}$ divisions of Bouma suggesting deposition mainly by low-density turbidity currents (Lowe, 1988). The succession contains the Nereites and Ophiomorpha rudis ichnofacies. 
Deposition by low-density turbidity currents and thin sandstone beds alternating with mudstones are typical of the distal environment in a turbidite system (e.g., Remacha and Fernandez, 2003) or of on intrafan environment (e.g., Hodgson, 2009). However, evidence for gradual shallowing based on the foraminiferal assemblages (Olszewska, 1984; Uchman et al., 2006) may also be suggesting deposition on a submarine slope/ramp after shut-down of the source of the sand-prone turbidite system of the Cisna Formation. The varying sandstone:mudstone ratio in the section studied probably reflects changes in sediment supply due to shift of deltaic lobes on a shelf, irregular tectonic activity and climate changes (Leszczyński, 1996).

Alternating sandstones and mudstones of the Submenilite Formation gradually pass into a $150 \mathrm{~m}$ thick succession of mudstones, menilitic cherts and fine-grained sandstones. These deposits represent the Menilite Formation (Early Oligocene) with the sandstone-rich member of the Cergowa Beds. The fine-grained part of the formation contains 4 to $7.1 \mathrm{~m}$ thick intervals of organic-rich, dark menilite-type claystones separated by intervals of pale to dark gray mudstone and thin fine-grained sandstone beds. These sediments sandwich a $50 \mathrm{~m}$ thick interval of Cergowa sandstones. They are characterized by alternations of thick-bedded, amalgamated and often scoured medium-grained sandstones and dark mudstones and black menilites showing an upwards thinning trend. In the lower part of the interval the sandstones are mostly massive and contain scattered small mudstone clasts. There are a few sandstone debrite - sandstone triplets indicating hybrid flows. Upwards, this succession is gradually replaced by fine-grained sandstones showing tractional structures. The sandstone to mudstone ratio changes from 4:1 to $1: 2$ as the Cergowa sandstones passes into the menilite shales. Frequent sole marks indicate a palaeoflow direction from NW to SE with minor flutes suggesting flow from NE to SW. The sandstones are locally deformed by synsedimentary faults and folds (Fig. 5) crossing part of the sedimentary succession. At the base of the sandstones the ichnofossil Scolicia was found.

The lower part of the succession, consisting of mudstones and thin beds of sandstone, reflects quiet hemipelagic/pelagic deposition occasionally interrupted by low-density turbidites. The thick sandstone beds of he Cergowa sandstones record increased tectonic activity related to the advancing orogen (e.g., Oszczypko and Oszczypko-Clowes, 2009). The common association with abundant carbonaceous matter indicates probable linkage to the contemporaneous shelf (e.g., Haughton et al., 2009). This is also supported by the occurrence of thick, often amalgamated sandstones with loaded bases suggesting high sediment input and proximity to the source area. The thick sandstone beds are intercalated with menilite cherts interpreted as condensed horizons. Their presence could represent significant intervals of time during which the turbidite pathways on the slopes were steepened by faulting (e.g., Fugelli and Olsen, 2007). A similar succession in the Dukla Unit, interpreted as a seismoturbidite, was described by Ślączka and Walton (1992). The fining-upward trend of the whole succession may be interpreted as gradual smoothing of the equilibrium profile that had been disrupted by an earlier tectonic event, resulting in gradual replacing of of high-density turbidity currents and hybrid flow deposits by deposits of low-density turbidity currents.

The menilite shales are overlain by heterolithic of deposits the Krosno Formation (Oligocene) that terminates the sedimentary succession of the Dukla Unit. The formation is characterized by thin-bedded, parallel-, ripple- and trough cross-laminated sandstones alternating with thin to medium parallel-laminated mudstone beds. The sandstone to mudstone ratio is about $1: 2$.

Thin sandstone beds with tractional structures overlain by mudstones represent the $\mathrm{Tb}, \mathrm{c}, \mathrm{d}$ interval of Bouma sequences deposited by low-density turbidity currents.

\section{DISCUSSION AND CONCLUSIONS}

It is generally accepted that the Outer Carpathian basins during their history represented constituents of distinct, but genetically consecutive basins (e.g., Oszczypko, 1999; Oszczypko et al., 2002; Golonka et al., 2003). The Cretaceous, Paleocene and Eocene strata are generally interpreted as sediments deposited in a remnant oceanic basin while the Oligocene sediments were deposited in a foreland basin that opened during the advance of the Carpathian orogen (e.g., Oszczypko, 1999, 2006; Golonka et al., 2011). The final phase of deposition occurred in wedge-top basins in some places (e.g., Oszczypko et al., 2002).

Based on the sedimentary record in the succession studied we interpret the following stages in the evolution of the Dukla Basin:

\section{FIRST STAGE}

The first stage is recorded by deposits of the Lupków and Cisna formations (Fig. 6). The base of the sedimentary succession recorded is typified by thickening-upward intervals of sandstones separated by mudstones, gradually passing to thick-bedded sandstones. The lower interval of high- to low-density turbidites deposited in a channel-lobe transition zone (Łupków Formation) and in the form of channelized lobes (Cisna Formation) implies progradation of the depositional system. Sources of these material lay to the NE and E of the basin, thus indicating the north-east promontory of the Marmarosh Massif (Bakk and Wolska, 2005) as well as the Bukowiec Palaeo-Ridge (in the case of the Cisna Formation, Ślączka, 2005) as their possible source.

\section{SECOND STAGE}

Lobes of the Cisna Formation were overlain by thinningand fining-upwards strata of the Submenilite Formation deposited by low- and, to lesser amount by high-density turbidity currents (Fig. 6). Two perpendicular palaeoflow directions (dominant SE to NW and minor N and NE to S and SW) recorded by Koráb and Durkovič (1978) as well as different sandstone mineralogical compositions (Koráb and Ďurkovič, 1978) indicate two depositional systems fed from different sources. Shallowing of the environment indicated by 
foraminiferal assemblages (Olszewska, 1984) suggests deposition on a submarine slope/ramp. The change in sediment input and shallowing probably results from increased tectonic activity connected with a new source area emerging between the Dukla and Magura basins (the Grybów Palaeo-Ridge, Cieszkowski, 2002).

\section{THIRD STAGE}

The third stage is characterized by deposition of dark to black mudstones of the Menilite Formation in the Early Oligocene (Fig. 6), during which significant changes of relative sea level took place as a result of eustatic fluctuation and tectonic activity (e.g., Oszczypko, 1999; Oszczypko et al., 2002; Poprawa et al., 2002; Golonka et al., 2003). The black mudstones containing much organic material suggest hemipelagic/pelagic and hemiturbidite sedimentation in anoxic conditions (Bessereau et al., 1996) resulting from sea level fall and related isolation of the basin. This quiet sedimentation changed abruptly, as recorded by the thick-bedded Cergowa sandstones interpreted as seismoturbidites (Fig. 6). The main NW to SE direction of palaeoflows transporting coarser-grained sediments indicates that the possible source of the material was the activated thrust belt of the Carpathian orogen (Silesian Palaeo-Ridge?). Finally, low-density turbidity currents entered the basin from the same direction and deposited the youngest synorogenic sediments of the unit terminated by the Krosno Formation. We assume that the increased tec- tonic activity is linked with the zipping of the subduction zone between the Carpathians and the adjacent European platform.

Based on this, we suggest that: ( 1$)$ the sediments of Łupków and Cisna Formation were deposited in conditions of a closing remnant basin; (2) the sediments of the Submenilite Formation, with a bipolar palaeoflow direction, represent a transitional phase between the remnant basin and the peripheral foreland basin and (3) deposition of Menilite and Krosno Fm. is associated with peripheral foreland basin that originated due to advance of the Carpathian orogen (Oszczypko, 1999; Poprawa et al., 2002; Golonka et al., 2011). This phase was characterized by periods of quiet sedimentation related to basin isolation and subsequent circulation slowdown ("menilitic deposition") interrupted by deposition of thick-bedded sandstones triggered by seismic events related to growth of the thrust belt in the hinterland of the Carpathian orogen front (deposits of Cergowa sandstone in the area studied and the Metresa Bed of Ślaczka and Walton, 1992). Terminal sedimentation is represented by thin-bedded, low-density turbidites of the Krosno Formation.

Acknowledgments. We are grateful to N. Oszczypko and T. Malata for their constructive comments, which have greatly improved this paper. Special thanks go to T. Peryt for his editorial efforts. The paper was written thanks to the support of the Operation Program Research and Development for Project 26220220031, co-financed from the resources of the European Foundation of Regional Development.

\section{REFERENCES}

AMY L.A. and TALLING P.J. (2006) - Anatomy of turbidites and linked debrites based on long distance $(120 \times 30 \mathrm{~km})$ bed correlation, Marnoso Arenacea Formation, Northern Apennines, Italy. Sedimentology, 53: 161-212

BAK K. and WOLSKA A. (2005) - Exotic orthogneiss pebbles from Paleocene flysch of the Dukla Nappe (Outer Eastern Carpathians, Poland). Geol. Carpath., 56 (3): 205-221.

BESSEREAU G., ROURE F., KOTARBA A., KUŚMIREK J. and STRZETELSKI W. (1996) - Structure and hydrocarbon habitat of the Polish Carpathians. Mém. Mus. Nat. Hist. Nat., 170: 343-373.

BOUMA A.H. (1962) - Sedimentology of some flysch deposits. Elsevier, Amsterdam.

CIESZKOWSKI M. (2002) - Fore-Magura zone in Polish sector of the Outer Carpathians. Geol. Carpath., 53 (Spec. Issue).

DEPTUCK M.E., PIPER D.J.W., SAVOYE B. and GERVAIS A. (2008) Dimensions and architecture of Late Pleistocene submarine lobes of the northern margin of East Corsica. Sedimentology, 55: 869-898.

DŻUŁYŃSKI S. (1996) - Erosional and deformational structures in single sedimentary beds: a genetic commentary. Ann. Soc. Geol. Pol., 66 (2): 101-189.

FELIX M., LESZCZYŃSKI S., ŚLACZKA A., UCHMAN A., AMY L. and PEAKALL J. (2009) - Field expressions of the transformation of debris flows into turbidity currents, with examples from the Polish Carpathians and the French Maritime Alps. Mar. Petrol. Geol., 26: $1-10$.

FUGELLI E. and OLSEN T. (2007) - Delineating confined slope turbidite systems offshore mid-Norway: the Cretaceous deep-marine Lysing Formation. AAPG Bull., 91 (11): 1577-1601.
GOLONKA J., OSZCZYPKO N. and ŚLĄCZKA A. (2000) - Late Carboniferous-Neogene geodynamic evolution and palaeogeography of the circum-Carpathian region and adjacent areas. Ann. Soc. Geol. Pol., 70 (2): 107-136

GOLONKA J., OSZCZYPKO N., MALATA T., POPRAWA P., KROBICKI M. and SLOMKA T. (2003) - Geodynamic evolution stages in the Outer Carpathians. GeoLines, 16: 31-32.

GOLONKA J., PIETSCH K. and MARZEC P. (2011) - Structure and Plate Tectonic Evolution of the Northern Outer Carpathians. In: Tectonics (ed. E. Closson). InTech, Available from: http://www.intechopen.com/articles/show/title/structure-and-plate-tectonic-evolution-of-the-northern-outer-carpathians.

HAUGHTON P.D.W., BARKER S.P. and MCCAFFREY W. (2003) Linked debrites in sand-rich turbidite systems - origin and significance. Sedimentology, 50: 459-482.

HAUGHTON P.D.W., DAVIS CH., McCAFFREY W. and BARKER S (2009) - Hybrid sediment gravity flow deposits - classification, origin and significance. Mar. Petrol. Geol., 26: 1-19.

HISCOTT R.N., PICKERING K.T., BOUMA A.H., HEND B.M., KNELLER B.C., POSTMA G. and SOH W. (1997) - Basin-floor fans in the North Sea: sequence stratigraphic models vs. sedimentary facies: discussion. AAPG Bull., 81: 662-665.

HODGSON D.M. (2009) - Origin and distribution of bipartite beds in sand-rich submarine fans: constraints from the Tanqua depocentre, Karoo Basin, South Africa. Mar. Petrol. Geol., 26: 1940-1956.

HODGSON D.M., FLINT S.S., HODGETTS D., DRINKWATER N.J., JOHANNESSEN E.P. and LUTHI S.M. (2006) - Stratigraphic evolution of fine-grained submarine fan systems, Tanqua Depocentre, Karoo Basin, South Africa. J. Sedim. Res., 76: 19-39. 
HUANG H., IMRAN J. and PIRMEZ C. (2007) - Numerical modelling of poorly sorted depositional turbidity currents. J. Geoph. Res., 112: $1-15$.

HURST A., VERSTRALEN I., CRONIN B. and HARTLEY A. (1999) Sand-rich fairways in deep-water clastic reservoirs: genetic units, capturing uncertainty and a new approach to reservoir modeling. AAPG Bull., 83: 1096-1118.

ITO M. (2008) - Downfan transformation from turbidity currents to debris flows at a channel-to-lobe transitional zone: the Lower Pleistocene Otadai Formation, Boso Peninsula, Japan. J. Sedim. Res., 78: $668-682$.

JANKOWSKI L., KOPCIOWSKI R. and RYŁKO W. (2004) - Geological map of the Outer Carpathians: borderlands of Poland, Ukraine and Slovakia. Pol. Geol. Inst., Warsaw.

KNELLER B.C. and BRANNEY M.J. (1995) - Sustained high-density turbidity currents and the deposition of thick massive sands Sedimentology, 42: 607-616.

KORÁB T. (1983) - Geologická mapa Nízkych Beskýd - východná čast’. Regionálne geologické mapy Slovenska M 1:50 000. GÚDŠ, Bratislava.

KORÁB T. and ĎURKOVIČ T. (1978) - Geológia dukelskej jednotky (Flyš východného Slovenska). GÚDŠ, Bratislava.

KOVÁČ M., NAGYMAROSY A., OSZCZYPKO N., ŚLĄCZKA A., CSONTOS L., MARUNTEANU M., MATENCO L. and MARTON E. (1998) - Palinspastic reconstruction of the Carpathian-Pannonian region during the Miocene. In: Geodynamic Development of the Western Carpathians (ed. M. Rakuš): 189-217. GÚDŠ, Bratislava.

LESZCZYŃSKI S. (1996) - Origin of lithological variation in the sequence of the Sub-Menilite Globigerina marl at Znamirowice (Eocene-Oligocene transition, Polish Outer Carpathians). Ann. Soc. Geol. Pol., 66 (3-4): 245-267.

LEŠKO B. and SAMUEL O. (1968) - Geológia východoslovenského flyšu. Vyd. SAV, Bratislava.

LOWE D.R. (1988) - Suspended-load fallout rate as an independent variable in the analysis of current structures. Sedimentology, 35 (5): $765-776$.

LOWE D.R. (1982) - Sediment gravity flows: II. Depositional models with special reference to the deposits of high-density turbidity currents. J. Sedim. Petrol., 52: 279-297.

MALATA T. and POPRAWA P. (2006) - Evolution of the Dukla Basin. In: Palaeotectonic Evolution of the Outer Carpathian and Pieniny Klippen Belt Basins (eds. N. Oszczypko, A. Uchman and E. Malata): 101-110. Inst. Geol. Sc., Jagiellonian Univ., Kraków.

McCAFFREY W.D. and KNELLER B. (2001) - Process controls on the development of stratigraphic trap potential on the margins of confined turbidite systems and aids to reservoir evaluation. AAPG Bull., 85 (6): 971-988.

McCAFFREY W.D., CHOUX C.M., BAAS J.H. and HAUGHTON P.D.W. (2003) - Spatio-temporal evolution of velocity structure, concentration and grain-size stratification within experimental particulate gravity currents. Mar. Petrol. Geol., 20: 851-860.

MULDER T., MIGEON S., SAVOYE B. and FAUGERES J.C. (2001) - Inversely graded turbidite sequences in the deep Mediterranean: a record of deposits from flood-generated turbidity currents. Geol. Mar. Lett., 21: 86-93.

MULDER T., RAZIN P. and FAUGERES J.C. (2009) - Hummocky cross-stratification-like structures in deep-sea turbidites: Upper Cretaceous Basque basins (Western Pyrenees, France). Sedimentology, 56: 997-1015.

MULDER T. and ALEXANDER A. (2001) - The physical character of subaqueous sedimentary density flows and their deposits. Sedimentology, 48: 269-299.

NEMČOK M., KRZYWIEC P., WOJTASZEK M., LUDHOVÁ L., KLECKER R.A., SERCOMBE W.J. and COWARD M.P. (2006) Tertiary development of the Polish and eastern Slovak parts of the Carpathian accretionary wedge: insights from balanced cross-sections. Geol. Carpath., 57 (5): 355-370.

NEMEC W. and STEEL R. (1988) - Fan Deltas - Sedimentology and Tectonic Settings. Blackie, London.

OLSZEWSKA B. (1984) - Benthic Foraminifera of the Submenilite Globigerina Marls of Polish Outer Carpathians (in Polish with English summary). Prace Inst. Geol., 110: 1-37.
OLSZEWSKA B. and MALATA E. (2006) - Analiza paleośrodowiskowa i paleobatymetryczna zespołów mikroskamieniałosci polskich Karpat zewnetrznych. In: Palaeotectonic Evolution of the Outer Carpathian and Pieniny Klippen Belt Basins. (eds: N. Oszczypko, A. Uchman and E. Malata): 61-84. Inst. Nauk Geol. Uniw. Jagiellońskiego, Kraków.

ONDRA P. and HANÁK J. (1989) - Petrofyzikální studium sedimentú východoslovenského flyše. Geol. Pr., Spr. 89: 67-97.

OSZCZYPKO N. (1999)-From remnant oceanic basin to collision-related foreland basin - a tentative history of the Outer Carpathians. Geol. Carpath., 50 (Spec. Issue): 161-163.

OSZCZYPKO N. (2004) - The structural position and tectonosedimentary evolution of the Polish Outer Carpathians. Prz. Geol., 52 (8/2): 780-791.

OSZCZYPKO N. (2006) - Late Jurassic-Miocene evolution of the Outer Carpathian fold-and-thrust belt and its foredeep basin (Western Carpathians, Poland). Geol. Quart., 50 (1): 169-194.

OSZCZYPKO N. and OSZCZYPKO-CLOWES M. (2009) - Stages in Magura Basin: a case study of the Polish sector (Western Carpathians). Geodynam. Acta, 22 (1-3): 83-100.

OSZCZYPKO N., GOLONKA J., MALATA T., POPRAWA P., SŁOMKA T. and UCHMAN A. (2002) - Tectono-stratigraphic evolution of the Outer Carpathian basins (Western Carpathians, Poland). Geol. Carpath., 53 (Spec. Issue).

OSZCZYPKO-CLOWES M. and OSZCZYPKO N. (2004) - The position and age of the youngest deposits in the Mszana Dolna and Szczawa tectonic windows (Magura Nappe, Western Carpathians, Poland). Acta Geol. Pol., 54 (3): 339-367.

PICKERING K., STOW D., WATSON M. and HISCOTT R. (1986) Deep-water facies, processes and models: a review and classification scheme for modern and ancient sediments. Earth-Sc. Rev., 23: 75-174.

PLINK-BJÖRKLUND P. and STEEL R.J. (2004) - Initiation of turbidity currents: outcrop evidence for Eocene hyperpycnal flow turbidites. Sed. Geol., 165: 29-52.

POPRAWA P., MALATA T., OSZCZYPKO N., SŁOMKA T. and GOLONKA J. (2002) - Subsidence versus Deposition - Quantitative Analysis for the Polish Outer Carpathian Basins. Geol. Carpath., 53 (Spec. Issue).

POSTMA G., CARTIGNY M. and KLEVERLAAN K. (2009) Structureless, coarse-tail graded Bouma Ta formed by internal hydraulic jump of the turbidity current? Sedim. Geol., 219: 1-6.

PRAVE A.R. and DUKE W. (1990) - Small-scale hummocky cross-stratification in turbidites: a form of antidune stratification? Sedimentology, 37: 531-539.

PRITCHARD D. and GLADSTONE C. (2009) - Reversing buoyancy in turbidite currents: developing a hypothesis for flow transformation and for deposit facies and architecture. Mar. Petrol. Geol., 26: 1997-2010.

PSZONKA J. (2009) - The influence of sedimentation and diagenetic processes on economic significance of the Cergowa sandstones from "Lipowica II-1" deposit. Gosp. Sur. Miner., 25: 333-342.

PUGLISI D., BADESCU D., CARBONE S., CORSO S., FRANCHI R., GIGLIUTO L.G., LOIACONO F., MICLAUS C. and MORETTI E. (2006) - Stratigraphy, petrography and paleogeographic significance of the Early Oligocene „,menilite facies“ of the Tarcau Nappe (Eastern Carpathians, Romania). Acta Geol. Pol., 56 (1): 105-120.

REINECK H.E. and SINGH I.B. (1980) - Depositional Sedimentary Environment, 2.ed. Springer-Verlag, Berlin, Heidelberg, New York.

REMACHA E. and FERNANDÉZ L. P. (2003) - High-resolution correlation patterns in the turbidite systems of the Hecho Grop (South-Central Pyrenees, Spain). Mar. Petrol. Geol., 20: 711-726.

RICCI LUCCHI F. and VALMORI E. (1980) - Basin-wide turbidites in a Miocene, over-supplied deep-sea plain: a geometrical analysis. Sedimentology, 27: 241-270.

SOTÁK J. (2010) - Paleoenvironmental changes across the Eocene-Oligocene boundary: insights from the Central-Carpathian Paleogene Basin. Geol. Carpath., 61 (5): 393-418.

STOW D.A.V. and JOHANSSON M. (2000) - Deep-water massive sands: nature and hydrocarbon implications. Mar. Petrol. Geol., 17: 145-174.

ŚLĄCZKA A. (1971) - Geologia jednostki dukielskiej. Prace Państw. Inst. Geol., 63: 1-77. 
ŚLĄCZKA A. (2005) - Bukowiec Ridge: A cordillera in front of the Dukla Basin (Outer Carpathians). Min. Slov., 37: 255-256.

ŚLACZKA A. and KAMINSKI M.A. (1998) - A Guidebook to Excursions in the Polish Flysch Carpathians. Grzybowski Found. Spec. Publ., 6.

ŚLACCZKA A. and WALTON E.K. (1992) - Flow characteristics of Metresa: an Oligocene seismoturbidite in the Dukla Unit, Polish Carpathians. Sedimentology, 39: 383-392.

TALLING P.J., AMY L.A., WYNN R.B., PEAKALL J. and ROBINSON M. (2004) - Beds comprising debrite sandwiched within cogenetic turbidite: origin and widespread occurrence in distal depositional environments. Sedimentology, 51: 163-194.
TALLING P.J., WYNN R.B., MASSON D.G., FRENZ M., CRONIN B.T., SCHIEBEL R., AKMETZHANOV A.M., DALLMEIER-TIESSEN A., BENETTI S., WEAVER P.P.E., GEORGIOPOULOU A., ZUHLSDORFF C. and AMY L.A. (2007) - Onset of submarine debris flow deposition far from giant landslide. Nature, 450: 531-544.

UCHMAN A., MALATA E., OLSZEWSKA B. and OSZCZYPKO N. (2006) - Paleobathymetry of the Outer Carpathian basins. In: Paleotectonic Evolution of the Outer Carpathian and Pieniny Klippen Belt Basins. (eds. N. Oszczypko, A. Uchman and E. Malata): 85-102. Inst. Nauk Geol. Uniw. Jagiellońskiego, Kraków. 